Article

\title{
Analysis of Oribatid Fauna of the East European Tundra with First Reported Data of Subpolar Urals
}

\author{
Elena N. Melekhina
}

Institute of Biology, Komi Science Center, Ural Branch of Russian Academy of Sciences (IB FRC Komi SC UB RAS), Kommunisticheskaya Str. 28, 167982 Syktyvkar, Russia; melekhina@ib.komisc.ru

Received: 1 May 2020; Accepted: 6 June 2020; Published: 10 June 2020

\begin{abstract}
This study presents data on the oribatid mite fauna of the Subpolar Urals for the first time. Observations were made in the Lembekoyu River valley and 35 species of oribatid mites from 24 genera and 21 families were found. The analysis of taxonomic diversity and distribution of East European tundra oribatid mite species is presented based on available literature and the author's own research findings. The taxonomic list includes 163 species from 81 genera and 45 families. Ceratozetidae (15 species), Crotoniidae (14 species), Oppiidae (12 species), Suctobelbidae (12 species), Damaeidae (9 species), Brachychthoniidae (8 species), Phthiracaridae (5 species), Humerobatidae (5 species), Achipteriidae (5 species), Punctoribatidae (5 species), and Galumnidae (5 species) are the leading families, comprising more than $58 \%$ of all species. The zoogeographical structure of the fauna is dominated by widely distributed Holarctic, cosmopolitan, and semi-cosmopolitan species. The share of Palaearctic species is $23 \%$. The specificity of the fauna of East European tundra manifests itself in the small group of Arctic species, both in the mainland tundra and on the Arctic islands. A complex of arctic-boreal species, widely distributed in the Eurasian sector of the Arctic, is distinguished.
\end{abstract}

Keywords: Arctic; Oribatida; faunistics; taxonomic diversity; distribution; checklist; arctic species; arctic-boreal species

\section{Introduction}

Interest in Arctic invertebrates has greatly increased in recent decades [1-14]. Coulson et al. [11] summarises data on the taxonomic composition of invertebrates from three archipelagos in the Barents Sea: Spitsbergen, Franz Josef Land, and Novaya Zemlya. One of the directions of modern research is to learn how invertebrates spread and what contributes to their faunistic diversity on the islands and archipelagos in the Arctic [15-18]. Makarova et al. [19] focused on 'eastern elements' in the invertebrate fauna of East European tundra, the so-called 'Siberian' species. An integrated assessment of biological diversity, including soil invertebrates, has been carried out in the large Arctic region, Nenets Autonomous District [20].

Attention is being paid to the study of taxonomic diversity of invertebrates, including oribatid mites, in anthropogenic altered soils in the Arctic and Sub-Arctic conditions and the application of this group of animals in bioindication [13,21-23]. Inventory of modern biodiversity and study of geographic trends of soil fauna diversity is important for biodiagnostics of natural communities under conditions of anthropogenic impact and forecasting changes in these communities in the long-term. In addition, the study of modern biodiversity is important for assessing the changes that take place in response to global warming.

In the European North-East, studies on oribatid mite fauna have been conducted both in the mainland tundra (plain and mountain tundra) and on the Arctic islands. The first data on Vaigach Island oribatid mites were presented in the form of a monograph by Koch [24], who processed the data 
collected by Adolf Nordenskiöld during his Arctic expedition of 1875. Koch named eight species of oribatids found on the Vaigach Island, four of which he described as new to science. Subsequently, Trägårdh [25] identified three species from Nordenskiöld's collection, which were already named by Koch. Krivolutsky et al. [26] provided a list of oribatid species in the Russian Arctic sector known at the time of publication, which included data on the Vaigach and Kolguev Islands. Melekhina et al. [27] studied oribatid fauna in the nests of Lapland Bunting Calcarius lapponicus and reported nine species, nine genera, and six families of oribatids new to Vaigach Island. In total, 25 species of oribatid mites from 24 genera and 21 families were found in this study. The authors compiled a list of Vaigach oribatid mites (43 species, 34 genera, 25 families) and analysed the zoogeographic structure of the fauna and species distribution [27].

Melekhina and Zinovyeva [28] collected samples in the north-western part of the Yugor Peninsula, on the Pai-Khoi Ridge. Oribatida from seven types of habitats of mainland tundra and mountain tundra, as well as one intrazonal plant community (motley grass meadow on the bank of the stream) were examined.

Data on the Bolshezemelskaya tundra have been collected mainly from around Vorkuta [29-31]. Melekhina and Krivolutsky [30] presented a list of oribatids of the Bolshezemelskaya tundra (33 species, 24 genera, 20 families). Peculiarities of the vertical distribution of oribatid mites in moss-lichen tundra with permafrost soil and in the tundra of dwarf birch with non-frost soil have also been reported [31]. Zubrii et al. [32] studied the plant communities near the thermal springs of Pym-Va-Shor located in the Bolshezemelskaya tundra in the Polar Pre-Urals. Samples from melted soil plots and watered mossy turfs were collected during the winter.

Research was also carried out in the Polar Urals in the area of Labytnangi [33], on the Rai-Iz Ridge [34]. Melekhina [35,36] obtained data in the vicinity of Lake Paga-Ty. Six types of mountain tundra habitats were surveyed: shrub-moss-lichen tundra, shrub-moss tundra, shrub-green-moss birch, grassy willow, horsetail moss willow, and motley grass in the hollow of the drain.

Sidorchuk [37] investigated the distribution of oribatid mites along with the vertical profile of the Malyy Paypudynskiy Ridge, from the floodplain to the belt of stony tundra. Samples were collected from the lower part of the Malaya Paypudyna River valley (settlement Polyarny, Labytnang district, YNAD), on the slope of the north-eastern exposure. Sidorchuk [37] found 82 species of oribatid mites in four types of plant communities, of which 46 were recorded for the first time in the region. The article provides a generalised list of oribatid mites of the Polar Urals (106 species, 61 genera, 34 families) taking into account all published data.

Melekhina conducted research at the tundra landscapes of the complex reserve 'Khrebtovy', located on the south-eastern slope of the Yenganepe Ridge (Polar Urals) [38]. Oribatida from seven types of habitats were examined: birch forest, larch sparse woodland, shrubby moss-lichen tundra, large bog, rocky outcrops, shrubby lichen tundra, and meadow complex.

Data on the mountain tundra oribatid fauna of the Northern Urals are also available. Melekhina [39] surveyed four types of plant communities (spruce, boggy grass-marsh, shrubby lichen, and stony lichen tundra) on the Yany-Pupu-Nyor mountain in the Pechora-Ilychsky Reserve. Melekhina [40] summarised her own research findings and those available in the literature on the taxonomic diversity of oribatids in the European North of Russia (in the taiga and tundra zones) and analysed the dynamics of diversity along the latitudinal gradient. In the Subpolar Urals, no research has been conducted on the oribatid mite fauna so far.

The purpose of this paper is to summarise the findings of the available literature and those of the author's own new research on the taxonomic diversity and distribution of oribatid mites in the East European tundra and to identify specific features of this fauna.

\section{Materials and Methods}

Observations were made in the Lembekoyu River valley $\left(65^{\circ} 16^{\prime} 46^{\prime \prime} \mathrm{N}, 60^{\circ} 4^{\prime} 51^{\prime \prime} \mathrm{E}\right)$, in zonal (lichen-moss tundra, moss-marsh tundra) and intrazonal (stream floodplain) communities. Sampling 
was conducted in five plant communities: lichen-moss tundra 1, lichen-moss tundra 2, moss and dwarf birch tundra 1, moss and dwarf birch tundra 2 and grassy community in a creek valley. Field material was collected according to generally accepted methods [41]. Ten soil samples, each with dimensions $10 \times 10 \mathrm{~cm}$ by $10 \mathrm{~cm}$ deep, were taken from all sites in June 2018. A total of 50 soil samples were collected. The soil samples were transported to the Institute of Biology (IB Komi SC UB RAS), Syktyvkar, and placed into Tullgren soil extractors. The microarthropod fauna was extracted under $40 \mathrm{Watt}$ bulbs into $96 \%$ alcohol for seven-ten days until the soil was completely dry. The Oribatida were identified to species by morphological taxonomic characters [42]. A total of 2500 specimens of adult oribatid mites were identified up to the species level.

In this manuscript, the author summarises the results of her own research conducted earlier in the tundra zone of the European North-East and presented in publications [22,27-32,35,36,38,39], new data obtained in the Subpolar Urals, as well as all available literature information (Table 1, Figure A1). Taxonomies of oribatid mites and types of global distribution of the species follow Subías [43]. For the analysis of the geographical distribution of species, literary sources were used $[1,7,11,30,44-50]$ and others. The term local fauna was used as understood by A.G. Tatarinov [51].

Table 1. Number of taxa of oribatid mites in the local fauna of East European tundra.

\begin{tabular}{|c|c|c|c|c|}
\hline \multirow{2}{*}{ Local Fauna } & \multirow{2}{*}{ Issue } & \multicolumn{3}{|c|}{ Taxa } \\
\hline & & Species & Genera & Families \\
\hline Kolguev Island & Krivolutsky et al., 2003 & 13 & 11 & 11 \\
\hline \multirow{4}{*}{ Vaygach Island } & Koch, 1879 & 8 & 6 & 6 \\
\hline & Trägårdh, 1904 & 3 & 2 & 2 \\
\hline & Krivolutsky et al., 2003 & 25 & 23 & 18 \\
\hline & Melekhina et al., 2019 & 43 & 34 & 25 \\
\hline Yugor Peninsula & Melekhina and Zinovyeva, 2012 & 32 & 26 & 19 \\
\hline \multirow{5}{*}{ Bolshezemelskaya tundra } & Melekhina, 1997 & 5 & 4 & 4 \\
\hline & Melekhina and Krivolutsky, 1999 & 33 & 24 & 20 \\
\hline & Goryachkin et al., 2011 & 22 & 22 & 18 \\
\hline & Zubrii et al., 2011 & 8 & 8 & 8 \\
\hline & Melekhina, unpublished & 7 & 7 & 7 \\
\hline \multirow{5}{*}{ Polar Urals } & Karpova and Poryadina, 1978 & 18 & 12 & 12 \\
\hline & Grishina, 1985 & 6 & 5 & 5 \\
\hline & Biodiversity, 2007 & 37 & 28 & 19 \\
\hline & Sidorchuk, 2009 & 106 & 61 & 34 \\
\hline & The biological diversity, 2010 & 32 & 27 & 18 \\
\hline Subpolar Urals & $\begin{array}{c}\text { Melekhina and Selivanova, } \\
\text { unpublished }\end{array}$ & 35 & 24 & 21 \\
\hline Northern Urals & Melekhina, 2005 & 25 & 22 & 14 \\
\hline a complete list of species & all published and new data & 163 & 81 & 45 \\
\hline
\end{tabular}

Synonyms follow Subías [43]. Synonyms of species were given when the author of a publication mentioned the species using a different name. For example, the species Eupelops plicatus (Koch, 1835) (=Pelops auritus Koch, 1839) was noted in Bolshezemelskaya tundra [30] and was named Eupelops auritus Koch, 1839. In some cases, a synonym was given if the authors of several publications cited synonyms. 


\section{Results and Discussion}

\subsection{Taxonomic Diversity}

\subsubsection{Subpolar Urals}

This is the first report of oribatid mite fauna of the Subpolar Urals. In total, 35 species, 24 genera, and 21 families of oribatid mites were found (Table 2, Appendix B). The largest number of species was recorded in the families Crotoniidae, Oppiidae and Suctobelbidae. In the studied five plant communities, 11 to 18 species were found. Heminothrus (H.) longisetosus, Nanhermannia (N.) sellnicki, Tectocepheus velatus and Melanozetes sellnicki were common in different types of communities. The species Malaconothrus (M.) monodactylus, Heminothrus (P.) peltifer, Hypochthonius rufulus, Atropacarus (A.) striculus and Neoribates (N.) aurantiacus were recorded only in the floodplain of the stream. The first two species are known to prefer high humidity habitats.

Table 2. The species composition of oribatid mites in the plant communities of the Subpolar Urals.

\begin{tabular}{|c|c|c|c|c|c|c|}
\hline $\mathbf{N}$ & Species & L-m 1 & L-m 2 & M-d 1 & M-d 2 & Gras. Com. \\
\hline 1 & Liochthonius (L.) sellnicki & + & + & + & - & - \\
\hline 2 & Hypochthonius rufulus & - & - & - & - & + \\
\hline 3 & Atropacarus (A.) striculus & - & - & - & - & + \\
\hline 4 & $\begin{array}{c}\text { Malaconothrus (M.) } \\
\text { monodactylus }\end{array}$ & - & - & - & - & + \\
\hline 5 & Nothrus borussicus & + & + & - & - & - \\
\hline 6 & Nothrus pratensis & - & - & + & - & + \\
\hline 7 & Camisia (C.) biurus & + & - & + & - & - \\
\hline 8 & Camisia (C.) segnis & - & - & + & - & - \\
\hline 9 & Camisia (E.) lapponica & - & - & - & + & - \\
\hline 10 & Heminothrus (H.) longisetosus & + & + & + & + & - \\
\hline 11 & Heminothrus (P.) peltifer & - & - & - & - & + \\
\hline 12 & Nanhermannia (N.) sellnicki & - & + & + & + & + \\
\hline 13 & Tokukobelba compta & - & + & - & - & - \\
\hline 14 & Damaeus (E.) bituberculatus & - & + & - & - & - \\
\hline 15 & Ceratoppia bipilis & + & - & - & + & - \\
\hline 16 & Ceratoppia quadridentata & - & - & - & + & - \\
\hline 17 & Rhinoppia (R.) subpectinata & + & + & - & - & - \\
\hline 18 & Oppiella (O.) nova & + & - & + & - & - \\
\hline 19 & Oppiella (M.) neerlandica & + & + & + & - & - \\
\hline 20 & Quadroppia (Q.) quadricarinata & - & + & - & - & - \\
\hline 21 & Suctobelbella (S.) acutidens duplex & - & + & - & - & - \\
\hline 22 & Suctobelbella (S.) latirostris & + & - & - & - & - \\
\hline 23 & Suctobelbella (S.) singularis & + & + & - & - & - \\
\hline 24 & Carabodes (C.) labyrinthicus & - & + & - & - & - \\
\hline 25 & Carabodes (C.) marginatus & - & + & + & + & - \\
\hline 26 & Carabodes (C.) subarcticus & - & + & - & + & - \\
\hline 27 & Tectocepheus velatus & + & + & + & + & + \\
\hline 28 & Parachipteria punctata & - & - & + & - & + \\
\hline 29 & Ceratozetes (C.) gracilis & + & - & - & + & + \\
\hline 30 & Melanozetes sellnicki & + & + & + & + & - \\
\hline 31 & Diapterobates oblongus & + & + & - & + & - \\
\hline 32 & Oribatula (O.) tibialis & - & + & + & - & - \\
\hline 33 & Oribatula (Z.) exilis & + & - & + & - & - \\
\hline 34 & Scheloribates (S.) laevigatus & - & - & - & + & + \\
\hline \multirow[t]{2}{*}{35} & Neoribates (N.) aurantiacus & - & - & - & - & + \\
\hline & total & 15 & 18 & 14 & 12 & 11 \\
\hline
\end{tabular}

Notes. L-m 1 lichen-moss tundra 1; L-m 2 lichen-moss tundra 2; M-d 1 moss and dwarf birch tundra 1; M-d 2 moss and dwarf birch tundra 2; Gras. com. grassy community in a creek valley; + and - The presence or absence of a species. 


\subsubsection{Total Number of Taxa at Different Levels}

In total, 163 species of oribatid mites from 81 genera and 45 families were found in East European tundra (Table 1, Appendix B). Oribatid species found in the East European tundra are grouped into 23 superfamilies, with the majority of the species coming under six superfamilies. The leading superfamily is Ceratozetoidea, with 28 species from four families, followed by Crotonioidea (22 species, four families), Oppioidea (16 species, four families), Trizetoidea (12 species, one family), Oripodoidea (12 species, six families), and Damaeoidea (10 species, two families) (Figure 1). Eight species represent the superfamilies Brachychthonioidea (one family), Gustavioidea (three families), and Achipterioidea (two families). A similar distribution of species among superfamilies has been observed, for example, in Svalbard [7].

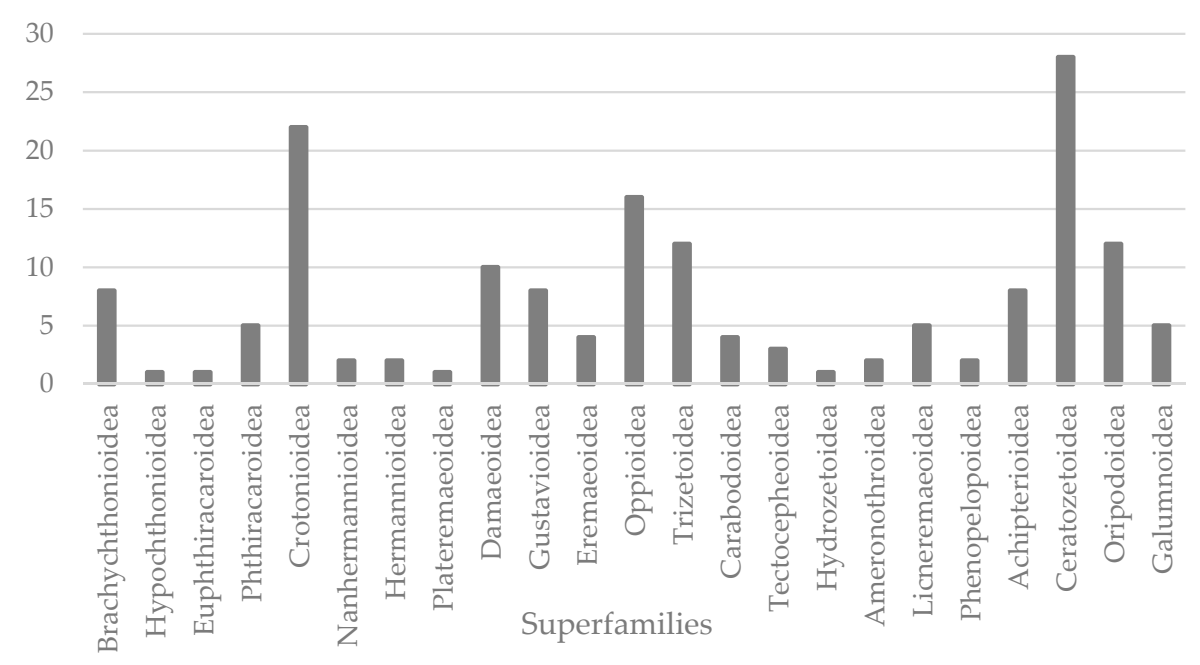

Figure 1. Distribution of species richness among different superfamilies of oribatid mites in the East European tundra (taxa are in a systematic order).

Leading families in the mite fauna are: Ceratozetidae (15 species), Crotoniidae (14 species), Oppiidae (12 species), Suctobelbidae (12 species), Damaeidae (nine species), Brachychthoniidae (eight species), Phthiracaridae (five species), Humerobatidae (five species), Achipteriidae (five species), Punctoribatidae (five species), and Galumnidae (five species). These 11 families comprise $58.6 \%$ of all species (95 species). Most families are represented by a small number of species (one to three) (Figure 2).

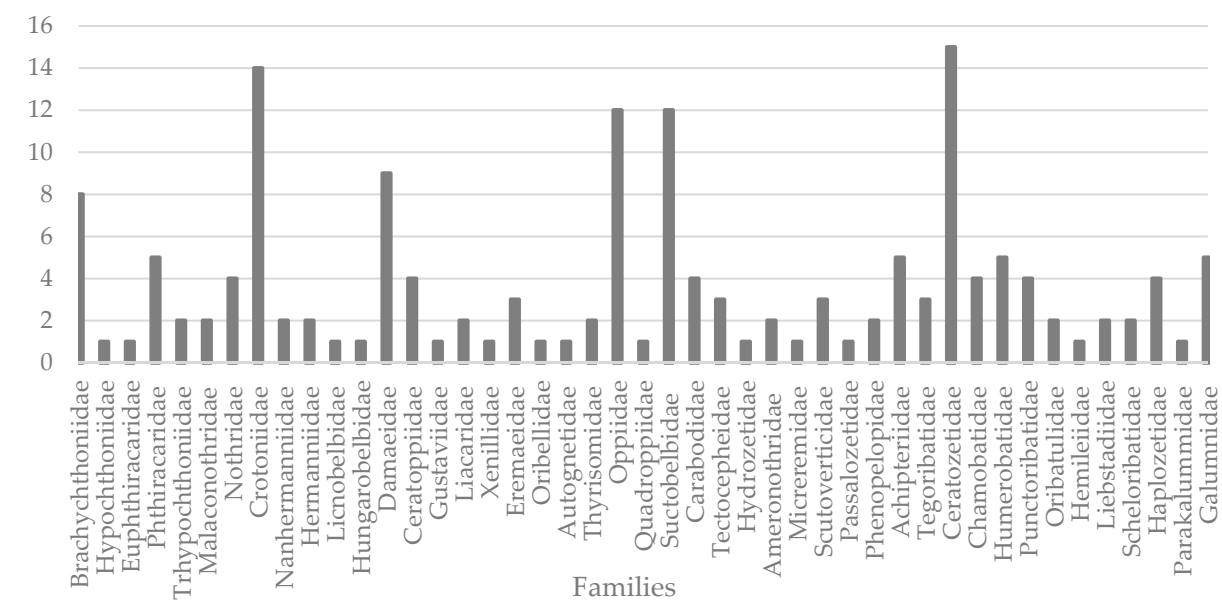

Figure 2. Distribution of species richness among different families of oribatid mites in the East European tundra (taxa are in a systematic order). 


\subsubsection{Characteristic Families Typical of Tundra Zone Species}

It is possible to distinguish species characteristics of different families for the East European tundra. From Crotoniidae, Heminothrus (Platynothrus) punctatus and Camisia (C.) horrida are consistently found in the local tundra fauna. Both species are often found in the Eurasian sector of the Arctic [28]. Camisia (C.) biverrucata, C. (C.) invenusta, and C. (Ensicamisia) lapponica, are associated with high latitude. Hermannia reticulata and H. scabra Hermanniidae and Ceratoppia bipilis and C. sphaerica Ceratoppiidae are also characteristic of high latitudes. In the tundra zone, the holarctic species Nothrus borussicus Nothridae was often observed.

From Carabodidae, the most common species in the tundra are the circumpolar Carabodes labyrinthicus and the Palearctic C. subarcticus and C. marginatus. For high latitudes, there are Holarctic species Oppiella (M.) neerlandica, O. (O.) splendens, and Moritzoppia unicarinata unicarinata Oppiidae, and Suctobelbella acutidens acutidens Suctobelbidae. From Ceratozetidae, Edwardzetes edwardsi and Ceratozetella sellnicki are common at high latitudes. Diapterobates notatus and Svalbardia paludicola Humerobatidae are widely distributed in the Eurasian sector of the Arctic; they are found on the Arctic islands and archipelagos [11-13,17]. The first of these species has been noted as the most abundant in various plant communities in Svalbard [11-13].

This complex of species is characteristic of local fauna of the East European tundra, as well as of the tundra zone of Eurasia as a whole. The Holarctic species Oribatula (O.) tibialis and O. (Z.) exilis, the cosmopolitan Tectocepheus velatus and Oppiella nova, and the semi-cosmopolitan Quadroppia quadricarinata and Scheloribates laevigatus laevigatus also are widely distributed in the Arctic.

For 11 species in the list, Subías [43] indicates boreo-Alpine distribution. These are Holarctic species C. (E.) lapponica, C. (C.) borealis, H. (P.) peltifer, H. (P.) humicola, E. edwardsi, Melanozetes mollicomus, Moritzoppia unicarinata clavigera, D. notatus, S. paludicola, Mycobates (Calyptozetes) sarekensis, and Oromurcia lucens. For the Holarctic species C. sphaerica, Melanozetes sellnicki, Ameronothrus lineatus, A. nigrofemoratus, Diapterobates variabilis, and Sphaerozetes arcticus, boreal distribution is indicated. In conclusion, all these species are typical of the high latitudes of Eurasia.

\subsection{Types of Longitudinal Distribution}

In this section, the Holarctic, Palearctic, cosmopolitan and semi-cosmopolitan species of oribatid fauna are distinguished by their longitudinal distribution. Holarctic species predominate the fauna (Figure 3). For comparison, in Spitsbergen, Holarctic species make up 50\% of all species [7,11]. It has previously been noted that the European sector of the Arctic is characterised by an increase in the proportion of Holarctic oribatid species in the latitudinal gradient, from the taiga to mainland tundra to the Arctic islands and archipelagos [40]. Thus, in the taiga zone of the European North-East, the share of Holarctic species (41.5\%) is the least [40].

The share of Palearctic species (34 species) in the local fauna was much smaller (23.4\%) than that of Holarctic species. For comparison, in the taiga zone of the European North-East, Palearctic species make up $37.5 \%$ of the faunal list [40]. The highest share of Palearctic species is observed in the fauna of the Polar Urals and Bolshezemelskaya tundra (Figure 3).

The composition of the Palearctic species was specific to each local fauna. In total, five Palearctic species from Damaeidae were recorded, four of which were found only in the Polar Urals. Only one species, Damaeus (E.) bituberculatus, was distributed in three local faunas: in the Bolshezemelskaya tundra, the Polar Urals and the Northern Urals. This species is widely distributed in the taiga zone of the European North [44].

Some Palearctic species were noted only in the Polar Urals: Liacarus (D.) neonominatus (Liacaridae), Eueremaeus oblongus silvestris (Eremaeidae), Exochocepheus laticuspis (Scutoverticidae), Bipassalozetes (B.) intermedius (Passalozetidae), and Suctobelbella (S.) subcornigera vera (Suctobelbidae). In turn, other palearctic species, Scutovertex neonominatus (Scutoverticidae), Berniniella (B.) bicarinata and Lauroppia falcata (Oppiidae), and Suctobelbella (S.) singularis (Suctobelbidae), were recorded only in the Bolshezemelskaya tundra. 


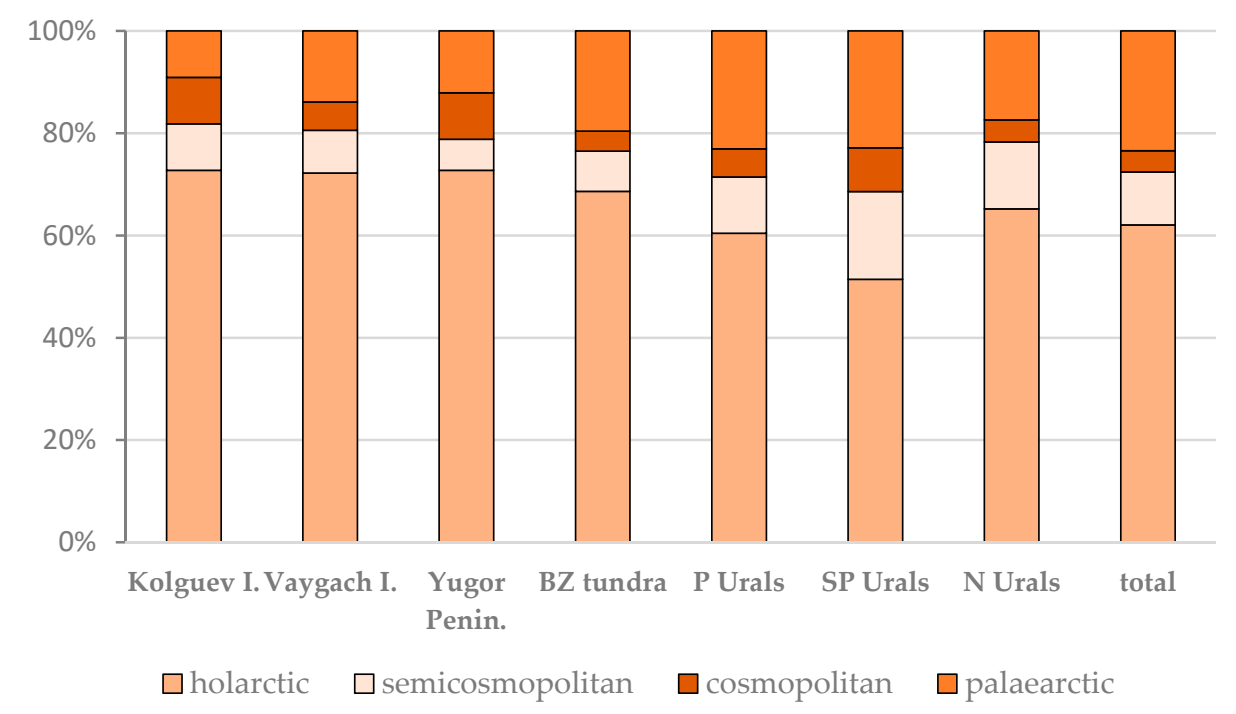

Figure 3. Relative species richness according to the longitudinal distribution of oribatid mites in the local fauna of East European tundra. Kolguev I.-Kolguev Island, Vaygach I.-Vaygach Island, Yugor Penin.-Yugor Peninsula, BZ tundra-Bolshezemelskaya tundra, P Urals-Polar Urals, SP Urals-Subpolar Urals, N Urals-North Urals.

Only a few Palearctic species were common to several local faunas. In addition to D. (E.) bituberculatus mentioned above, the species Carabodes (C.) marginatus was recorded in four mainland faunas: Polar Urals, Subpolar Urals, Yugor Peninsula, and Bolshezemelskaya tundra. The generalisate Palearctic species for two faunas: the Yugor Peninsula and the Vaigach Island was Minunthozetes (M.) pseudofusiger.

The share of cosmopolitan and semi-cosmopolitan species in the total fauna structure is $14.5 \%$. In local faunas, they account for $13.9 \%$ to $18.2 \%$. This is much higher than their share in the taiga zone, where they account for $9.5 \%$ of the total species [40].

It can thus be concluded that the findings of previous research [40] regarding the decrease in the proportion of Palearctic species and the increase in the proportion of Holarctic, cosmopolitan, and semi-cosmopolitan species in the oribatid fauna along the latitudinal gradient (from the taiga to mainland tundra to the Arctic islands and archipelagos) holds true.

A substantial number of species (20 species, $62.5 \%$ ) are distributed circumpolar; they occur in high latitudes of both the Palearctic and Nearctic regions- in Alaska, Yukon, and Greenland [10,47,49]. These include Liochthonius lapponicus, N. borussicus, Camisia horrida, C. biurus, H. (P.) punctatus, H. reticulata, C. bipilis, C. sphaerica, Moritzoppia neerlandica, M. unicarinata clavigera, S. acutidens acutidens, S. hammeri, O. tibialis, M. mollicomus, D. notatus, S. paludicola, as well as cosmopolitan species T. velatus, O. nova, C. gracilis and semi-cosmopolitan species Q. quadricarinata.

\subsection{Types of Latitudinal Distribution}

\subsubsection{Arctic Species}

In the composition of the oribatid fauna of the East European tundra, species with arctic, arctic-boreal, temperate, and polyzonal types of latitudinal distribution have been documented. For the East European tundra, as well as for the mainland tundra of the European part of Russia as a whole, only a single Arctic oribatid species is known until now - S. paludicola. In addition to the Eastern European sector, S. paludicola was found in the Kola Peninsula [50]. In the Arctic archipelagos of the Palearctic region, it was found in Spitsbergen [7,11] and Novaya Zemlya [1,11]; in northern Siberia, in Yamal and Taimyr [34,45]; and in the northern Far East, in Chukotka [48]. The species has a circumpolar distribution and is found in Greenland [49], Alaska, and Yukon [47]. The data obtained confirm earlier 
conclusion about the small number of Arctic species in the Eastern European sector of the Arctic, both in the island and mainland regions $[28,40]$.

The oribatid species Sphaerozetes arcticus Hammer, 1952, noted in the Polar Urals [35], should be referred to as an arctic-boreal species. In the European part of Russia, this species is rarely found. In addition to the Polar Urals, the species was recorded in the taiga zone, in the Arkhangelsk region [44]. In northern Siberia, it is more widespread, with its distribution covering the arctic-boreal zone, but most findings are in the tundra zone [45]. The species is found in Chukotka. Thus, it can be concluded that S. arcticus is characteristic of high latitudes. Subías [43] indicates a boreal distribution of this species.

The number of Arctic species is increasing on remote islands and archipelagos of the European Arctic sector. For example, on the Svalbard archipelago, where 81 species of oribatid mites are known [7,11], six Arctic species have been recorded. These are: Autogneta (A.) kaisilai Karppinen, 1967, Sphaerozetes setiger (Trägårdh, 1910), Iugoribates gracilis Sellnick, 1944, Svalbardia paludicola, Ceratozetes (C.) spitsbergensis Thor, 1934, and Oribatella (O.) arctica arctica Thor, 1930. The first of these species is noted only on Svalbard [43] and can be called conditional endemic to Svalbard.

For comparison, two Arctic species, S. paludicola and Oribatella (O.) arctica arctica, have been registered in the fauna of Novaya Zemlya. Oribatella (O.) arctica arctica, was observed in northern Siberia [34] and Chukotka [45], in addition to Spitsbergen. Therefore, it cannot be ruled out that this species may be found in the East European tundra in the future.

\subsubsection{Arctic-Boreal Species}

The tundra oribatid fauna includes a complex of arctic-boreal species occupying the Arctic islands and archipelagos, the continental part of the tundra zone, and the taiga zone of Eurasia. The base of this complex is represented by species that constitute the majority of tundra fauna, both in the European sector of the Arctic (mainland part and island part: Vaigach Island, Novaya Zemlya, and Spitsbergen), and in Siberia and the Far East, and, accordingly, contribute to the higher percentage of tundra fauna similarity in Eurasia. These species are H. punctatus, C. sphaerica, H. reticulata, and D. notatus, with a circumpolar distribution. On Vaigach Island, this list further includes Ameronothrus lineatus, A. nigrofemoratus, and Oromurcia lucens. Species A. lineatus in the European sector of the Arctic is also distributed in Spitsbergen and Kola tundra. Like A. nigrofemoratus, it is also a boreal species, while Oromurcia lucens (L. Koch, 1879), also found on Spitsbergen, is a boreal-alpine species, according to Subías [43].

In the biocoenoses of the Pai-Khoi Ridge (Yugor peninsula), the complex of arctic-boreal species is complemented by Moritzoppia unicarinata clavigera, Pyroppia lanceolata, and Banksinoma setosa. For the first of these species, Subías [43] indicates a boreal-alpine distribution. The species B. setosa, in addition to the Yugor peninsula, is noted in the North Urals. It is mainly located in the Siberian and Far Eastern sectors. The share of arctic-boreal species in different local faunas is not high, making up $7.7 \%$ to $18.6 \%$ of the total fauna. In the overall structure of the fauna, their contribution is $7.4 \%$.

Some arctic-boreal species are also present in the Palaearctic mountain ranges, such as D. notatus in the Altai [46], C. sphaerica in the Tien Shan [46], and M. unicarinata clavigera and P. lanceolata in the Caucasus [41]. Arctic-boreal species H. punctatus, D. notatus, Hermannia scabra, H. reticulata, A. lineatus, and C. sphaerica are also found in the Western European tundra sector (Kola Peninsula) [50]. It can be thus concluded that the arctic-boreal species which are widely distributed along the longitudinal gradient of the European sector of the Arctic are all common. No arctic-boreal species specific to the Eastern European sector have been identified. In the European North-East, the complex of arctic-boreal species also includes M. unicarinata clavigera, P. lanceolata, B. setosa, Sphaerozetes arcticus, and Peloribates pilosus.

\subsubsection{Temperate and Polyzonal Species}

The largest number of species recorded in the East European tundra have a temperate or polyzonal type of latitudinal distribution. Temperate species typical of East European tundra are Liochthonius 
lapponicus, N. borussicus, O. (M.) neerlandica, C. labyrinthicus, C. marginatus. C. subarcticus, E. edwardsi, and M. mollicomus.

Polyzonal species C. horrida, C. biurus, N. borussicus, S. acutidens acutidens, S. acutidens duplex, C. bipilis, O. (O.) tibialis, and O. (Z.) exilis were often found in local faunas of the tundra zone. Cosmopolitan species T. velatus and O. nova and semi-cosmopolitan species $Q$. quadricarinata and S. laevigatus, which in the latitudinal aspect are also distributed polyzonal [52], are common in the tundra. These polyzonal and temperate species that are common in the tundra zone, as well as the Arctic and arctic-boreal species, mentioned above, we call 'species of northern complex'.

\subsection{4. 'Southern' Elements within the Oribatid Fauna}

Attention is also drawn to species which are mainly found in the lower latitudes. These species can be called 'conditionally southern'. For example, Hydrozetes thienemanni, with a temperate type of distribution, was found only at Yugor Peninsula in the European sector of the tundra zone [28]. In the European part of Russia, it is distributed in taiga and coniferous/broad-leaved forests [41,44,52]. In the tundra zone of Eurasia, H. thienemanni was previously found only in Chukotka by Grishina [34].

Holarctic species Malaconothrus (Trimalaconothrus) tardus, according to Subías [43], is absent in the northern Palaearctic region. It is found in the Polar Urals [35]. In the European part of Russia, it is found in the northernmost regions. This species was observed mainly in broad-leaved forests and steppe zone $[41,44]$.

Palaearctic species Eueremaeus oblongus silvestris found in the Polar Urals [37] is not characteristic of the tundra zone. In the European part of Russia, it is mainly found in the zone of broad-leaved and coniferous/broad-leaved forests [41,52]. In Siberia, the species was observed in taiga forests and the Altai [45].

\section{Summary}

This publication presents a generalised taxonomic list of oribatid mites of East European tundra, based on available literature and new data. The checklist of East European tundra oribatid mites includes 163 species, 81 genera, and 45 families. This study presents data on the oribatid mite fauna of the Subpolar Urals for the first time. To date, 35 species, 24 genera, and 21 families of oribatids have been registered from this region.

The leading families in the fauna structure are Crotoniidae, Ceratozetidae, Oppiidae, Suctobelbidae, Damaeidae, Brachychthoniidae, Phthiracaridae, Humerobatidae, Achipteriidae, Punctoribatidae, and Galumnidae. The greatest number of species is Holarctic. Circumpolar distributed species make 12.3\% of the total. The share of Palaearctic species is low $(23.4 \%)$, which distinguishes the fauna of the tundra zone from the taiga zone.

The specificity of the oribatid fauna of East European tundra manifests itself in the small group of Arctic species, both in the mainland tundra and on the Arctic islands. In the majority of local fauna, there is only one Arctic species, Svalbardia paludicola. Sphaerozetes arcticus, noted in the Polar Urals, that has been classified as an arctic-boreal species. It could also be called 'conditionally arctic', as it sometimes penetrates into the taiga zone.

The fauna of the East European tundra is characterised by a complex of arctic-boreal species, based on circumpolar species common with the Western European sector of the Arctic, as well as with the Siberian and Far Eastern sectors, such as Heminothrus punctatus, Ceratoppia sphaerica, Hermannia reticulata, and Diapterobates notatus. In different local faunas, this complex is complemented by species Ameronothrus lineatus, A. nigrofemoratus, Banksinoma setosa, Pyroppia lanceolata, Moritzoppia unicarinata clavigera, Peloribates pilosus, and Oromurcia lucens.

The largest number of species in the East European tundra is polyzonal. No species specific to the East European sector of the tundra zone was identified. 
Funding: This work was supported by the RFBR No. 18-29-05028 mk and State Assignment AAAA-A17 $-117112850235-2$.

Acknowledgments: The author thanks Leonid N. Rybin from the Institute of Biology, Komi Science Center, Ural Branch of RAS, Syktyvkar (Russia) for map.

Conflicts of Interest: The author declares no conflict of interest.

\section{Appendix A}

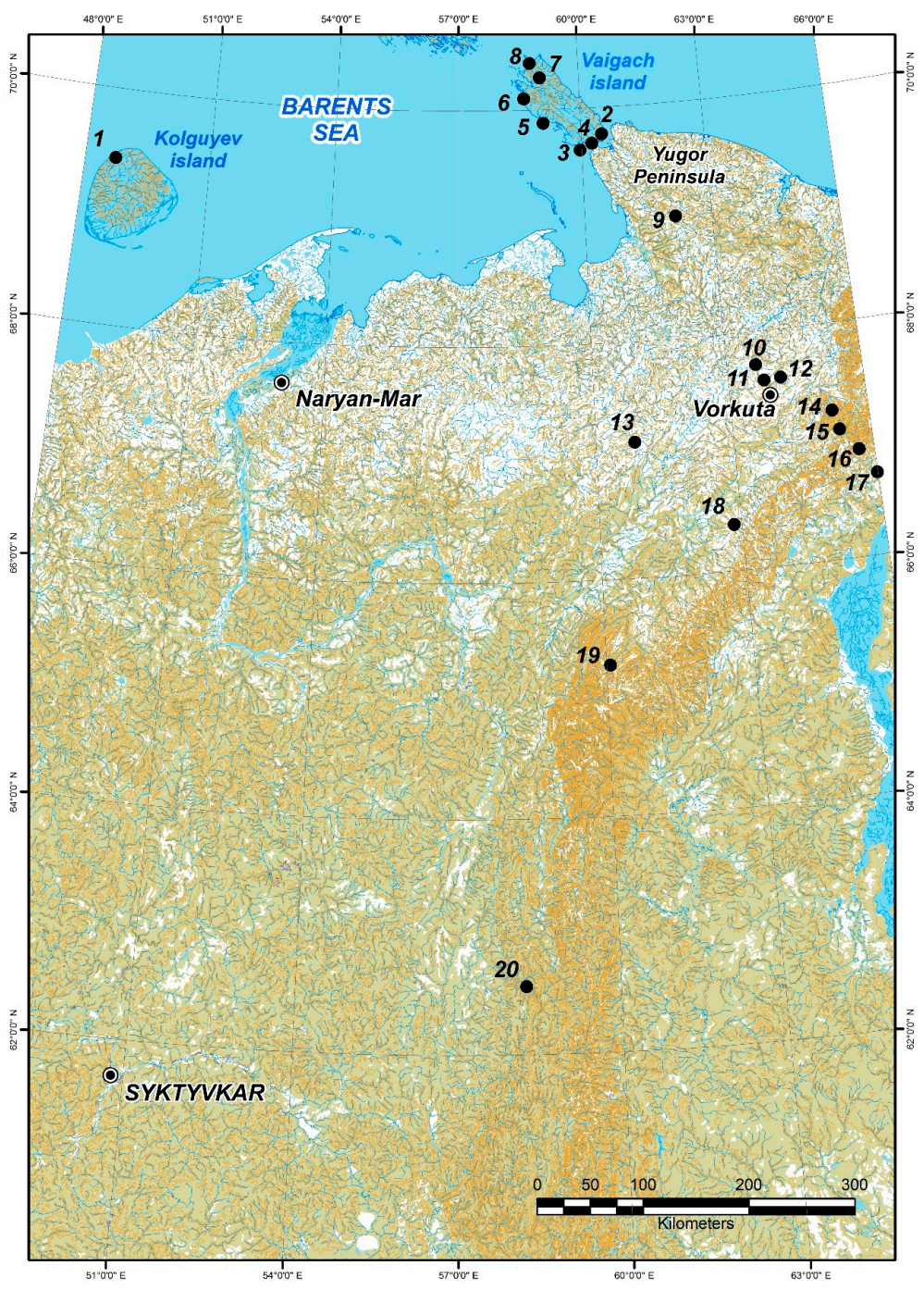

Figure A1. Localities within the region under consideration (see Table 1 for explanations). 1-Kolguev Island (Krivolutsky et al., 2003), 2-Vaigach Island, Yugorskiy Shar (Koch, 1879), 3-Vaigach Island, Cape Greben' (Koch, 1879), 4-Vaigach Island (Trägårdh, 1904), 5 and 6-Vaigach Island (Krivolutsky et al., 2003), 7-Vaigach Island, Bolvansky mountain (Melekhina et al., 2019), 8-Vaigach Island, Old Polar Station (Melekhina et al., 2019), 9-Yugor Peninsula, Pai-Khoi Ridge (Melekhina and Zinovyeva, 2012), 10-Bolshezemelskaya tundra, Vorgashor village (Melekhina, 1997), 11-Bolshezemelskaya tundra, Vorkuta (Melekhina and Krivolutsky, 1999), 12-Bolshezemelskaya tundra, Vorkuta (Goryachkin et al., 2011), 13-Bolshezemelskaya tundra, Pym-Va-Shor (Zubrii et al., 2012), 14-Polar Urals, complex reserve 'Khrebtovy', Yenganepe Ridge (The biological ... , 2010), 15-Polar Urals, Polyarny village (Sidorchuk, 2009), 16-Polar Urals, Rai-Iz Ridge (Grishina, 1985), 17-Polar Urals, Labytnangi village (Karpova et al., 1987), 18-Polar Urals, Paga-Ty Lake (Biodiversity ... , 2007; Melekhina, 2008), 19-Subpolar Urals, Lembekoyu River (Melekhina and Selivanova, unpublished), 20-Northern Urals, Yany-Pupu-Nyor mountain (Melekhina, 2005). 


\section{Appendix B}

Checklist of oribatid mites of the East European tundra*

${ }^{*}$ Note. After the name of a species its distribution in the East European tundra with references is given; global distribution follows Subías [43].

Brachychthoniidae Thor, 1934

Brachychthonius bimaculatus Willmann, 1936 Polar Urals [37]. Holarctic

Liochthonius (Liochthonius) lapponicus (Trägårdh, 1910) Yugor Peninsula [28], Bolshezemelskaya tundra [31]. Holarctic

Liochthonius (L.) muscorum Forsslund, 1964 Polar Urals [37]. Holarctic

Liochthonius (L.) sellnicki (Thor, 1930) Kolguev Island [26], Vaygach Island [26,27], Polar Urals [35], Subpolar Urals (new data). Holarctic

Sellnickochthonius immaculatus (Forsslund, 1942) Polar Urals [37]. Holarctic

Sellnickochthonius zelawaiensis (Sellnick, 1928) Bolshezemelskaya tundra [Melekhina, unpabl.], Polar Urals [37]. Holarctic

Eobrachychthonius sp. Vaygach Island [26].

Eobrachychthonius latior (Berlese, 1910) Bolshezemelskaya tundra [31]. Holarctic

Hypochthoniidae Berlese, 1910

Hypochthonius rufulus Koch, 1835 Polar Urals [37], Subpolar Urals (new data). Semicosmopolitan

Euphthiracaridae Jacot, 1930

Acrotritia ardua (Koch, 1841) Polar Urals [37]. Cosmopolitan

Phthiracaridae Perty, 1841

Atropacarus (Atropacarus) striculus (Koch, 1835) Vaygach Island [27], Bolshezemelskaya tundra [32]; Subpolar Urals (new data). Semicosmopolitan

Phthiracarus spp. Kolguev Island [26], Vaygach Island [27].

Phthiracarus (Phthiracarus) boresetosus Jacot, 1930 Polar Urals [37]. Semicosmopolitan

Phthiracarus (P.) laevigatus (Koch, 1844) Vaygach Island (as Phthiracarus nitens Nicolet, 1855) [26]. Palaearctic

Phthiracarus (Archiphthiracarus) ligneus Willmann, 1931 Vaygach Island [27]. Holarctic

Trhypochthoniidae Willmann, 1931

Trhypochthonius cladonicolus (Willmann, 1919) Bolshezemelskaya tundra [30], Polar Urals [37]. Palaearctic

Trhypochthonius tectorum s. str. (Berlese, 1896) Bolshezemelskaya tundra [32];

Polar Urals [37]. Cosmopilitan

Malaconothridae Berlese, 1916

Malaconothrus (Malaconothrus) monodactylus (Michael, 1888) Bolshezemelskaya tundra [32]; Polar Urals [37], Subpolar Urals (new data). Holarctic

Malaconothrus (Trimalaconothrus) tardus (Michael, 1888) Polar Urals [35]. Holarctic

Nothridae Berlese, 1896

Nothrus sp. Vaygach Island [27].

Nothrus borussicus Sellnick, 1928 Yugor Peninsula [28], Bolshezemelskaya tundra [30,31]; Polar Urals [35,37,38]; Subpolar Urals (new data); Northern Urals [39]. Holarctic

Nothrus palustris Koch, 1839 Bolshezemelskaya tundra [30,32]. Holarctic

Nothrus pratensis Sellnick, 1928 Bolshezemelskaya tundra [30], Subpolar Urals (new data). Holarctic

Crotoniidae Thorell, 1876

Camisia (Camisia) biurus (Koch, 1839) Yugor Peninsula [28], Bolshezemelskaya tundra [31]; Polar Urals [35,37], Subpolar Urals (new data); Northern Urals [39]. Holarctic

Camisia (C.) biverrucata (Koch, 1839) Polar Urals [37]. Holarctic

Camisia (C.) borealis (Thorell, 1871) Vaygach Island [26], Polar Urals [37]. Holarctic 
Camisia (C.) horrida (Hermann, 1804) Vaygach Island [24], Yugor Peninsula [28], Bolshezemelskaya tundra [30], Polar Urals [35,37], Northern Urals [39]. Holarctic

Camisia (C.) invenusta (Michael, 1888) Polar Urals [37]. Palaearctic

Camisia (C.) segnis (Hermann, 1804) Polar Urals [37], Subpolar Urals (new data). Semicosmopolitan

Camisia (C.) spinifer (Koch, 1835) Polar Urals [37]. Semicosmopolitan

Camisia (Ensicamisia) lapponica (Trägårdh, 1910) Polar Urals [37]; Subpolar Urals (new data); Northern Urals [39]. Holarctic

Heminothrus (Capillonothrus) capillatus s. str. (Berlese, 1914) Kolguev Island (as Heminothrus septentrionalis Sellnick, 1944) [26]. Holarctic

Heminothrus (Capillonothrus) thori (Berlese, 1904) Polar Urals [37]. Holarctic

Heminothrus (Heminothrus) longisetosus (Willmann, 1925) Polar Urals [35,37,38]; Subpolar Urals (new data); Northern Urals [39]. Holarctic

Heminothrus (Platynothrus) humicola (Forsslund, 1955) Bolshezemelskaya tundra [31]. Holarctic

Heminothrus (Platynothrus) peltifer (Koch, 1839) Bolshezemelskaya tundra [31,32]; Polar Urals [35,37,38]; Subpolar Urals (new data); Northern Urals [39]. Semicosmopolitan

Heminothrus (Platynothrus) punctatus (L. Koch, 1879) Kolguev Island [26], Vaygach Island [26,27], Yugor Peninsula [28], Bolshezemelskaya tundra [30]. Holarctic

Nanhermanniidae Sellnick, 1928

Nanhermannia (Nanhermannia) dorsalis (Banks, 1896) Polar Urals [37]. Holarctic

Nanhermannia (N.) sellnicki Forsslund, 1958 Bolshezemelskaya tundra [32]; Subpolar Urals (new data); Northern Urals [39]. Palaearctic

Hermanniidae Sellnick, 1928

Hermannia (Heterohermannia) reticulata Thörell, 1871 Vaygach Island [24-26], Yugor Peninsula [28], Holarctic

Hermannia (Heterohermannia) scabra (L. Koch, 1879) Vaygach Island [24,25]. Holarctic

Licnobelbidae Grandjean, 1965

Licnobelba latiflabellata (Paoli, 1908) Kolguev Island (as Licnobelba alestensis Grandjean, 1931) [26]. Palaearctic

Hungarobelbidae Miko y Travé, 1996

Tokukobelba compta s. str. (Kulczynski, 1902) Yugor Peninsula (as Belba (Belba) compta (Kulczynski, 1902) [28], Polar Urals (as B. (B.) compta (Kulczynski 1902) [37], Subpolar Urals (new data). Palaearctic Damaeidae Berlese, 1896

Belba spp. Kolguev Island [26], Bolshezemelskaya tundra [31]; Northern Urals [39].

Belba (Belba) rossica Bulanova-Zachvatkina, 1962 Polar Urals [35]. Palaearctic

Damaeus (Damaeus) auritus Koch, 1835 Polar Urals [37]. Palaearctic

Damaeus (Epidamaeus) sp. Polar Urals [37].

Damaeus (Epidamaeus) bituberculatus (Kulczynski, 1902) Bolshezemelskaya tundra [30], Polar Urals [37], Subpolar Urals (new data); Northern Urals [39]. Palaearctic

Damaeus (Spatiodamaeus) boreus Bulanova-Zachvatkina, 1957 Polar Urals [37]. Palaearctic

Metabelba (Metabelba) pulverulenta (Koch, 1839) Polar Urals [35]. Holarctic

Porobelba spinosa (Sellnick, 1920) Polar Urals [37]. Palaearctic

Subbelba (Subbelba) montana (Kulczynski, 1902) Polar Urals [37]. Palaearctic

Ceratoppiidae Grandjean, 1954

Ceratoppia bipilis s. str. (Hermann, 1804) Yugor Peninsula [28], Bolshezemelskaya tundra [30,31]; Polar Urals [35,37], Subpolar Urals (new data); Northern Urals [39]. Holarctic

Ceratoppia sphaerica (L. Koch, 1879) Vaygach Island [26], Yugor Peninsula [28], Polar Urals [34,37]. Holarctic 
Ceratoppia quadridentata (Haller, 1882) Bolshezemelskaya tundra [30], Polar Urals [34,37], Subpolar Urals (new data). Holarctic

Pyroppia lanceolata Hammer, 1955 Yugor Peninsula [28]. Holarctic

Gustaviidae Oudemans, 1900

Gustavia microcephala (Nicolet, 1855) Vaygach Island [27]. Palaearctic

Liacaridae Sellnick, 1928

Adoristes (A.) ovatus poppei (Oudemans, 1906) Yugor Peninsula [28]. Holarctic

Liacarus (Dorycranosus) neonominatus Subías, 2004 Polar Urals [34,37]. Palaearctic

Xenillidae Woolley et Higgins, 1966

Xenillus (Xenillus) clypeator Robineau-Desvoidy, 1839 Polar Urals (as Cepheus latus Nicolet, 1855 [37]. Holarctic

Eremaeidae Oudemans, 1900

Eueremaeus oblongus s. str. (Koch, 1835) Vaygach Island [27]. Holarctic

Eueremaeus oblongus silvestris (Forsslund, 1956) Polar Urals [37]. Palaearctic

Tricheremaeus sp. Polar Urals [37].

Oribellidae Kunst, 1971

Proteremaeus sp. Polar Urals [37].

Autognetidae Grandjean, 1960

Autogneta (Conchogneta) traegardhi Forsslund, 1947 Polar Urals [33,37]. Holarctic

Thyrisomidae Grandjean, 1954

Banksinoma lanceolata s. str. (Michael, 1885) Vaygach Island [27], Bolshezemelskaya tundra [31]; Polar Urals [37]. Holarctic

Banksinoma setosa Rjabinin, 1974 Yugor Peninsula [28], Northern Urals [39]. Holarctic

Oppiidae Sellnick, 1937

Rhinoppia (Rhinoppia) subpectinata (Oudemans, 1900) Polar Urals [35,37], Subpolar Urals (new data); Northern Urals (as Medioppia tuberculata (Bulanova-Zachvatkina, 1964) [39]. Holarctic

Microppia minus s. str. (Paoli, 1908) Polar Urals [37]. Cosmopolitan

Berniniella (Berniniella) bicarinata (Paoli, 1908) Bolshezemelskaya tundra [30]. Palaearctic

Dissorhina ornata s. str. (Oudemans, 1900) Bolshezemelskaya tundra [31]. Holarctic

Lauroppia falcata (Paoli, 1908) Bolshezemelskaya tundra [30]. Palaearctic

Lauroppia fallax (Paoli, 1908) Polar Urals [37]. Semicosmopolitan

Lauroppia maritima acuminata (Strenzke, 1951) Polar Urals [37]. Holarctic

Oppiella (Moritzoppiella) neerlandica (Oudemans, 1900) (=Dameosoma translamellatum Willmann, 1923) Vaygach Island (as Oppia translamellata) [26], Yugor Peninsula (as Moritzoppia (Moritzoppiella) neerlandica (Oudemans, 1900) [28], Bolshezemelskaya tundra (as Lauroppia neerlandica (Oudemens, 1900) [30] and [31]; Polar Urals (as L. neerlandica (Oudemens, 1900) [35] and [33,37,38]; Subpolar Urals (new data); Northern Urals (as L. neerlandica (Oudemens, 1900) [39]. Holarctic

Oppiella (Oppiella) nova s. str. (Oudemans, 1902) Vaygach Island [26,27], Yugor Peninsula [28], Polar Urals [33,37,38]; Subpolar Urals (new data). Cosmopolitan

Oppiella (O.) splendens (Koch, 1841) Kolguev Island [26], Vaygach Island [26], Polar Urals [37]. Holarctic Moritzoppia unicarinata s. str. (Paoli, 1908) Vaygach Island [26], Polar Urals [33,37], Northern Urals [39]. Holarctic

Moritzoppia unicarinata clavigera (Hammer, 1952) Yugor Peninsula [28]. Holarctic

Quadroppiidae Balogh, 1983

Quadroppia (Quadroppia) quadricarinata (Michael, 1885) Vaygach Island [26,27], Yugor Peninsula [28], Bolshezemelskaya tundra [31]; Polar Urals [33,35,37,38]; Subpolar Urals (new data). Semicosmopolitan Suctobelbidae Jacot, 1938 
Suctobelbella (Suctobelbella) acutidens s. str. (Forsslund, 1941) Yugor Peninsula [28], Bolshezemelskaya tundra [30], Polar Urals [35,37]. Holarctic

Suctobelbella (S.) acutidens duplex (Strenzke, 1950) Yugor Peninsula (as S. hammerae Krivolutsky, 1965) [28], Bolshezemelskaya tundra (as S. hammerae Krivolutsky, 1965) [32]; Polar Urals [35], Subpolar Urals (new data). Holarctic

Suctobelbella (S.) acutidens sarekensis (Forsslund, 1941) Polar Urals [37] Holarctic

Suctobelbella (S.) arcana Moritz, 1970 Polar Urals [37]. Holarctic

Suctobelbella (S.) latirostris (Strenzke, 1950) Subpolar Urals (new data). Palaearctic

Suctobelbella (S.) longicuspis s. str. Jacot, 1937 Polar Urals [37]. Semicosmopolitan

Suctobelbella (S.) longirostris (Forsslund, 1941) Polar Urals [37]. Holarctic

Suctobelbella (S.) palustris (Forsslund, 1951) Bolshezemelskaya tundra [30]. Holarctic

Suctobelbella (S.) singularis (Strenzke, 1950) Bolshezemelskaya tundra [30], Subpolar Urals (new data). Palaearctic

Suctobelbella (S.) subcornigera s. str. (Forsslund, 1941) Polar Urals [37]. Semicosmopolitan

Suctobelbella (S.) subcornigera vera (Moritz, 1964) Polar Urals [37]. Palaearctic

Suctobelba spp. Vaygach Island [27], Bolshezemelskaya tundra [Melekhina, unpabl.].

Suctobelba trigona (Michael, 1888) Vaygach Island [26]. Holarctic

Carabodidae Koch, 1843

Carabodes (Carabodes) areolatus Berlese, 1916 Vaygach Island [27], Bolshezemelskaya tundra [30], Polar Urals [33-35]. Holarctic

Carabodes (C.) labyrinthicus (Michael, 1879) Kolguev Island [26], Vaygach Island [26], Polar Urals [35,37,38]; Subpolar Urals (new data). Holarctic

Carabodes (C.) marginatus (Michael, 1884) Yugor Peninsula [28]; Bolshezemelskaya tundra [31]; Polar Urals [33]; Subpolar Urals (new data). Palaearctic

Carabodes (C.) subarcticus Trägardh, 1902 Yugor Peninsula [28], Polar Urals [35,37,38]; Subpolar Urals (new data); Northern Urals [39]. Palaearctic

Tectocepheidae Grandjean, 1954

Tectocepheus minor Berlese, 1903 Kolguev Island [26]. Semicosmopolitan

Tectocepheus velatus s. str. (Michael, 1880) Kolguev Island [26], Vaygach Island [26,27], Yugor Peninsula [28], Bolshezemelskaya tundra [30], Polar Urals [33,35,37,38]; Subpolar Urals (new data); Northern Urals [39]. Cosmopolitan

Tectocepheus velatus sarekensis Trägårdh, 1910 Polar Urals [33,37]. Cosmopolitan

Hydrozetidae Grandjean, 1954

Hydrozetes thienemanni Strenzke, 1943 Yugor Peninsula [28]. Holarctic

Ameronothridae Vitzthum, 1943

Ameronothrus lineatus (Thorell, 1871) Vaygach Island [24]. Holarctic

Ameronothrus nigrofemoratus (L. Koch, 1879) Vaygach Island [24,25]. Holarctic

Micreremidae Grandjean, 1954

Micreremus brevipes (Michael, 1888) Polar Urals [37]. Palaearctic

Scutoverticidae Grandjean, 1954

Scutovertex minutus (Koch, 1835) Vaygach Island [27]. Holarctic

Scutovertex neonominatus Subías, 2004 Bolshezemelskaya tundra [Melekhina, unpabl.]. Palaearctic

Exochocepheus laticuspis (Balogh et Mahunka, 1965) Polar Urals [37]. Palaearctic

Passalozetidae Grandjean, 1954

Bipassalozetes (Bipassalozetes) intermedius (Mihelčič, 1954) Polar Urals [37]. Palaearctic

Phenopelopidae Petrunkevitch, 1955

Eupelops plicatus (Koch, 1835) (=Pelops auritus Koch, 1839) Bolshezemelskaya tundra (as Eupelops auritus Koch, 1839) [30], [31]; Polar Urals [35,37], Northern Urals [39]. Holarctic 
Eupelops torulosus s. str. (Koch, 1839) Polar Urals [37]. Palaearctic

Achipteriidae Thor, 1929

Campachipteria (Triachipteria) nivalis (Hammer, 1952) (Achipteria) Polar Urals [35]. Holarctic

Parachipteria punctata (Nicolet, 1855) Vaygach Island [26], Polar Urals [35], Subpolar Urals (new data). Holarctic

Achipteria sp. Vaygach Island [30].

Achipteria (Achipteria) nitens (Nicolet, 1855) Polar Urals [37]. Holarctic

Anachipteria (Anachipteria) howardi (Berlese, 1908) Polar Urals [37]. Holarctic

Tegoribatidae Grandjean, 1954

Scutozetes lanceolatus Hammer, 1952 Bolshezemelskaya tundra [30]. Holarctic

Tegoribates latirostris (Koch, 1844) Bolshezemelskaya tundra [30]. Palaearctic

Ceratozetidae Jacot, 1925

Ceratozetella (Ceratozetella) sellnicki (Rajski, 1958) Vaygach Island [26], Polar Urals [37]. Palaearctic

Ceratozetes sp. Polar Urals [38].

Ceratozetes (Ceratozetes) gracilis s. str. (Michael, 1884) Yugor Peninsula [28], Subpolar Urals (new data). Cosmopolitan

Edwardzetes (Edwardzetes) edwardsi (Nicolet, 1855) Yugor Peninsula [28], Bolshezemelskaya tundra [30],

Polar Urals [37,38]. Holarctic

Fuscozetes fuscipes (Koch, 1844) Bolshezemelskaya tundra [32]; Polar Urals [35]. Holarctic

Fuscozetes pseudosetosus Shaldybina, 1975 Bolshezemelskaya tundra [Melekhina, unpabl.]. Holarctic

Fuscozetes setosus (Koch, 1839) Polar Urals [33]. Holarctic

Melanzetes sp. Polar Urals [37].

Melanozetes mollicomus (Koch, 1839) Yugor Peninsula [28], Northern Urals [39]. Holarctic

Melanozetes sellnicki (Hammer, 1952) Kolguev Island (as Fuscozetes sellnicki Hammer, 1952) [26], Vaygach Island (as Fuscozetes sellnicki Hammer, 1952) [26], Polar Urals [37], Subpolar Urals (new data). Holarctic Trichoribates sp. Polar Urals (as Murcia (M.) sp.) [37].

Trichoribates (T.) novus s. str. (Sellnick, 1928) Yugor Peninsula (as Murcia nova Sellnick, 1928) [28], Bolshezemelskaya tundra [31]; Polar Urals (as Murcia (M.) nova Sellnick 1928) [35]. Holarctic

Trichoribates (T.) berlesei (Jacot, 1929) Vaygach Island [27], Bolshezemelskaya tundra (as Trichoribates trimaculatus Koch, 1835) [30]. Holarctic

Oromurcia lucens (L. Koch, 1879) Vaygach Island [24]. Holarctic

Trichoribates (Latilamellobates) incisellus s. str. (Kramer, 1897) Bolshezemelskaya tundra [Melekhina, unpabl.], Northern Urals [39]. Holarctic

Sphaerozetes arcticus Hammer, 1952 Polar Urals [35]. Holarctic

Chamobatidae Thor, 1937

Chamobates (C.) cuspidatus (Michael, 1884) Bolshezemelskaya tundra [31]; Polar Urals [35]. Holarctic

Chamobates (C.) lapidarius (Lucas, 1849) Vaygach Island [26]. Palaearctic

Chamobates (C.) pusillus (Berlese, 1895) Vaygach Island (as C. borealis) [26]. Palaearctic

Chamobates (Xiphobates) voigtsi (Oudemans, 1902) Polar Urals [37]. Palaearctic

Humerobatidae Grandjean, 1971

Diapterobates humeralis (Hermann, 1804) Polar Urals [35,37]. Holarctic

Diapterobates notatus (Thorell, 1871) Kolguev Island [26], Vaygach Island [24,26,27], Yugor Peninsula [28]. Holarctic

Diapterobates oblongus (L. Koch, 1879) Subpolar Urals (new data); Northern Urals [39]. Palaearctic

Diapterobates variabilis s. str. Hammer, 1955 Polar Urals [37]. Holarctic

Svalbardia paludicola Thor, 1930 Yugor Peninsula [28], Bolshezemelskaya tundra [Melekhina, unpabl.], Polar Urals [37]. Holarctic 
Punctoribatidae Thor, 1937

Mycobates (Mycobates) monodactylus Shaldybina, 1970 Polar Urals [33,35,37]. Palaearctic

Mycobates (Calyptozetes) patrius Shaldybina, 1970 Polar Urals [35]. Palaearctic

Mycobates (Calyptozetes) sarekensis (Trägårdh, 1910) Polar Urals [37]. Holarctic

Minunthozetes (M.) pseudofusiger (Schweizer, 1922) Vaygach Island [26], Yugor Peninsula [28]. Palaearctic Punctoribates (P.) punctum (Koch, 1839) Bolshezemelskaya tundra [30]. Semicosmopolitan

Oribatulidae Thor, 1929

Oribatula (Oribatula) tibialis (Nicolet, 1855) Vaygach Island [26], Yugor Peninsula [28], Bolshezemelskaya tundra [30], Polar Urals [33-35,37], Subpolar Urals (new data); Northern Urals [39]. Holarctic

Oribatula (Zygoribatula) exilis s. str. (Nicolet, 1855) Vaygach Island [24,27], Yugor Peninsula [28], Bolshezemelskaya tundra [30], Polar Urals [35,37], Subpolar Urals (new data); Northern Urals [39]. Holarctic

Hemileiidae J. et P. Balogh, 1984

Hemileius (Hemileius) initialis (Berlese, 1908) Bolshezemelskaya tundra (as Scheloribates confundatus Sellnick, 1928) [30]; Polar Urals (as S. confundatus Sellnick, 1928) [35] and [38]. Semicosmopolitan

Liebstadiidae J. et P. Balogh, 1984

Liebstadia (L.) pannonica (Willmann, 1951) Bolshezemelskaya tundra (as Protoribates pannonicus Willmann, 1951) [30]. Holarctic

Liebstadia (L.) similis (Michael, 1888) Kolguev Island [26], Vaygach Island [26,27], Polar Urals [35,37]. Holarctic

Scheloribatidae Grandjean, 1933

Scheloribates (S.) laevigatus s. str. (Koch, 1835) Vaygach Island [27], Yugor Peninsula [28], Subpolar Urals (new data); Northern Urals [39]. Semicosmopolitan

Scheloribates (S.) pallidulus latipes (Koch, 1844) Polar Urals [35,37,38];

Northern Urals [39]. Semicosmopolitan

Haplozetidae Grandjean, 1936

Peloribates spp. Vaygach Island [26,27].

Peloribates (Peloribates) canadensis Hammer, 1952 Polar Urals [37]. Holarctic

Peloribates (P.) europaeus Willmann, 1935 Bolshezemelskaya tundra [30]. Holarctic

Peloribates (P.) pilosus Hammer, 1952 Bolshezemelskaya tundra [30], Northern Urals [39]. Holarctic

Parakalummidae Grandjean, 1936

Neoribates (Neoribates) aurantiacus (Oudemans, 1914) Polar Urals [35,37], Subpolar Urals (new data). Holarctic

Galumnidae Jacot, 1925

Galumna (Galumna) dimorpha Krivolutskaja, 1952 Bolshezemelskaya tundra [Melekhina, unpabl.]. Palaearctic

Galumna (G.) rossica Sellnick, 1926 Polar Urals [37]. Palaearctic

Pergalumna sp. Bolshezemelskaya tundra [33].

Pergalumna (P.) nervosa s. str. (Berlese, 1914) Bolshezemelskaya tundra [30]. Holarctic

Pilogalumna sp. Polar Urals [35].

\section{References}

1. Krivolutsky, D.A.; Kalyakin, V.N. Microfauna of Soils in Ecological Control in Novaya Zemlya. In Novaya Zemlya; Nauka: Moscow, Russia, 1993; Volume 2, pp. 125-131. (In Russian)

2. Lebedeva, N.V.; Lebedev, V.D.; Melekhina, E.N. New data on the oribatid mite (Oribatei) fauna of Svalbard. Doklady Biol. Sci. 2006, 407, 182-186. [CrossRef] [PubMed]

3. Gwiazdowicz, D.J.; Gulvik, M.E. Mesostigmatid mites (Acari, Mesostigmata) in Svalbard. In Proceedings of the Materia y XXXII Sympozjum Polarnego, Toruń, Poland, 15-17 October 2020; pp. 32-34. 
4. Gwiazdowicz, D.J.; Teodorowicz, E.; Coulson, S.J. Redescription of Zercon solenites Haarløv, 1942 (Acari: Mesostigmata: Zerconidae) with a key to the Svalbard species of the genus Zercon. Int. J. Acarol. 2011, 37, 135-148. [CrossRef]

5. Gwiazdowicz, D.J.; Zawieja, B.; Olejniczak, I.; Skubała, P.; Gdula, A.K.; Coulson, S.J. Changing Microarthropod Communities in Front of a Receding Glacier in the High Arctic. Insects 2020, 11, 226. [CrossRef] [PubMed]

6. Avila-Jimenez, M.L.; Gwiazdowicz, D.J.; Coulson, S.J. The mesostigmatid mite (Acari: Parasitiformes) fauna of Svalbard: A revised inventory of a high Arctic archipelagos. Zootaxa 2011, 3091, 33-41. [CrossRef]

7. Bayartogtokh, B.; Schatz, H.; Ekrem, T. Distribution and diversity of the soil mites of Svalbard, with redescription of three known species (Acari: Oribatida). Int. J. Acarol. 2011, 37, 467-484. [CrossRef]

8. Melekhina, E.N.; Ryabinin, N.A. Analysis fauna oribatid mites (Oribatida) in tundra Russian zone. In Biodiversity of Ecosystems of the Far North: Inventory, Monitoring, Protection; Materials of reports of the All-Russian Conference; Institute of Biology of Komi Science Center of Ural Branch of Russian Academy of Sciences: Syktyvkar, Russia, 2013; pp. 462-463. (In Russian)

9. Makarova, O.L. Gamasid mites (Parasitiformes, Mesostigmata) of the European Arctic and their distribution patterns. Entomol. Rev. 2013, 93, 113-133. [CrossRef]

10. Makarova, O.L. The fauna of free-living mites (Acari) of Greenland. Entomol. Rev. 2015, 95, 108-125. [CrossRef]

11. Coulson, S.J.; Convey, P.; Aakra, K.; Aarvik, L.; Avila-Jimenez, M.L.; Babenko, A.; Biersma, E.; Bostrom, S.; Brittain, J.; Carlsson, A.M.; et al. The terrestrial and freshwater invertebrate biodiversity of the archipelagoes of the Barents Sea; Svalbard, Franz Josef Land and Novaya Zemlya. Soil Biol. Biochem. 2014, 68, 440-470. [CrossRef]

12. Coulson, S.J.; Schatz, H.; Gwiazdowicz, D.J.; Solhoy, T. The oribatid and mesostigmatid mite fauna (Acari) of the High Arctic island of Hopen. Pol. Polar Res. 2014, 35, 133-213. [CrossRef]

13. Coulson, S.J.; Fjellberg, A.; Melekhina, E.N.; Taskaeva, A.A.; Lebedeva, N.V.; Belkina, O.A.; Seniczak, S.; Seniczak, A.; Gwiazdowicz, D.J. Microarthropod communities of industrially disturbed or imported soils in the High Arctic; the abandoned coal mining town of Pyramiden, Svalbard. Biodivers. Conserv. 2015, 24, 1671-1690. [CrossRef]

14. Babenko, A.B.; Potapov, M.B.; Taskaeva, A.A. The collembolan fauna of the East- European tundra. Russ. Entomol. J. 2017, 26, 1-30. [CrossRef]

15. Lebedeva, N.V.; Krivolutsky, D.A. Bird spread soil microarthropods to Arctic Islands. Doklady Biol. Sci. 2003, 391, 329-332. [CrossRef] [PubMed]

16. Avila-Jimenez, M.L.; Coulson, S.J. A Holarctic biogeographical analysis of the Collembola (Arthropoda, Hexapoda) unravels recent Post-Glacial colonization patterns. Insects 2011, 2, 273-296. [CrossRef] [PubMed]

17. Coulson, S.J.; Fjellberg, A.; Gwiazdowicz, D.J.; Lebedeva, N.V.; Melekhina, E.N.; Solhøy, T.; Erséus, C.; Maraldo, K.; Miko, L.; Schatz, H.; et al. Introduction of invertebrates into the High Arctic via imported soils: The case of Barentsburg in the Svalbard. Biol. Invasions 2013, 15, 1-5. [CrossRef]

18. Avila-Jimenez, M.L.; Solhoy, T.; Gwiazdowicz, D.J.; Fjellberg, A.; Dózsa-Farkas, K.; Monson, F.; De Smet, W.H.; Stur, E.; Ekrem, T.; Coulson, S.J. The terrestrial invertebrate fauna of Edgeøya, Svalbard: Arctic landscape community composition reflects biogeography patterns. Polar Biol. 2019, 42, 837-850. [CrossRef]

19. Makarova, O.L.; Anufriyev, V.V.; Babenko, A.B.; Bizin, M.S.; Glazov, P.M.; Kolesnikova, A.A.; Marusik, Y.M.; Tatarinov, A.G. Fauna of the East European tundra: The input of "Siberian" species. Bull. North-East Sci. Cent. Russia Acad. Sci. Far East Branch 2019, 1, 59-71. (In Russian) [CrossRef]

20. Rozhnov, V.V.; Lavrinenko, I.A.; Razzhivin, V.Y.; Makarova, O.L.; Lavrinenko, O.V.; Anufriev, V.V.; Babenko, A.B.; Bizin, M.S.; Glazov, P.M.; Goryachkin, S.V.; et al. Biodiversity revision of a large arctic region as a basis for its monitoring and protection under conditions of active economic development (Nenetsky autonomous okrug, Russia). Nat. Conserv. Res. Zapovednaya nauka 2019, 4, 1-28. (In Russian) [CrossRef]

21. Coulson, S.J.; Fjellberg, A.; Gwiazdowicz, D.J.; Lebedeva, N.V.; Melekhina, E.N.; Solhøy, T.; Erséus, C.; Maraldo, K.; Miko, L.; Schatz, H.; et al. The invertebrate fauna of anthropogenic soils in the High Arctic settlement of Barentsburg; Svalbard. Polar Res. 2013, 32, 19273. [CrossRef]

22. Melekhina, E.N. Effect of pollucion upon the fauna of Oribatid mites in the Vorkuta tundra. In Cryopedology'97; Abstracts of the International Conference; Institute of Biology of Komi Science Center of Ural Branch of Russian Academy of Sciences: Syktyvkar, Russia, 1997; pp. 176-177. (In Russian) 
23. Melekhina, E.N. Recovery succession soil microfauna in oil-polluted ecosystems of European Subarctic. Biol. Bull. 2020, 47, 97-105. [CrossRef]

24. Koch, L. Arachniden aus Sibirien und Novaja Semlja eingesammelt von der schwedischen Expedition im Jahre 1875; Kongliga Svenska Vetenskaps Academiens Handlingar: Stockholm, Sweden, 1879; pp. 1-136.

25. Trägårdh, I. Monographie der arktischen Acariden. Fauna Arctica 1904, 4, 1-78.

26. Krivolutsky, D.A.; Drozdov, N.N.; Lebedeva, N.V.; Kalyakin, V.N. Geography of soil microarthropods on the Arctic Islands. Moscow Univ. Geogr. Bull. 2003, 6, 33-40. (In Russian)

27. Melekhina, E.N.; Matyukhin, A.V.; Glazov, P.M. Oribatid mites in nests of the Lapland Bunting (Calcarius lapponicus) on the arctic island of Vaygach (with analysis of the islands fauna). Proc. Karelian Sci. Cent. Russ. Acad. Sci. 2019, 8, 108-122. (In Russian)

28. Melekhina, E.N.; Zinovyeva, A.N. First data on oribatid mites (Acari: Oribatida) of Pay-Khoy ridge (Yugor peninsula). Proc. Komi Sci. Cent. Ural. Branch Russ. Acad. Sci. 2012, 2, 42-50. (In Russian)

29. Melekhina, E.N. Oribatid mites. In Tundra Animals. Vorkuta-A City on Coal, a City in the Arctic; Getsen, M.V., Ed.; Ministry of Natural Resources and Environmental Protection of the Komi Republic: Syktyvkar, Russia, 2011; pp. 172-175. (In Russian)

30. Melekhina, E.N.; Krivolutsky, D.A. List of the Oribatid Mites in the Republic of Komi; Komi Science Center of Ural Branch of Russian Academy of Sciences: Syktyvkar, Russia, 1999; pp. 1-24. (In Russian)

31. Goryachkin, S.V.; Gilichinskii, G.A.; Gubin, S.V.; Lapteva, E.M.; Lupachev, A.V.; Fedorov-Davydov, D.G.; Zazovskaya, E.P.; Mazhitova, G.G.; Mergelov, N.S.; Vinogradova, Y.A.; et al. A state of the Arctic and Subarctic soils with regard to the period of International Polar Year. In Polyarnaya Kriosfera i Vody Sushi; Paulsen: Moscow, Russia, 2011; pp. 193-218. (In Russian)

32. Zubrii, N.A.; Kolosova, Y.C.; Taskaeva, A.A.; Melekhina, E.N. Activity of soil and herpetobiont invertebrates during winters. In Funktsionirovanie Subarkticheskoi Gidrotermal'noi Ekosistemy v Zimnii Period; Bogolitcin, K.G., Bolotov, I.N., Eds.; UrO RAN: Ekaterinburg, Russia, 2011; pp. 183-193. (In Russian)

33. Karpova, N.I.; Poryadina, N.M. Oribatid mites in the forest-tundra soils Tyumen region. In Problems of Soil Zoology (Proceedings of the VI All-Union Conference); Science and Technology: Minsk, Belarus, 1978; pp. 108-109. (In Russian)

34. Grishina, L.G. Oribatid mites of the North of Siberia. In Arthropods of Siberia and the Far East; Nauka: Novosibirsk, Russia, 1985; pp. 14-24. (In Russian)

35. Getsen, M.V. Biodiversity of the Polar Urals Ecosystems; Institute of Biology of Komi Science Center of Ural Branch of the Russian Academy of Sciences: Syktyvkar, Russia, 2007; pp. 1-251. (In Russian)

36. Melekhina, E.N. Oribatid mites in western slopes of the Polar Urals and Northern Urals. In Biodiversity, Environmental Problems of the Altai Mountains and Adjacent Regions: Present, Past, Future; Materials of the International Conference; Part I; Gorno-Altaisk State University: Gorno-Altaisk, Russia, 2008; p. 324. (In Russian)

37. Sidorchuk, E.A. New data on the fauna of Oribatid mites (Acari, Oribatida) from the Polar Urals. Entomol. Rev. 2009, 89, 554-563. [CrossRef]

38. Degteva, S.V. The Biological Diversity of Komi Republic Protected Areas. Issue 7. Natural Complexes of "Khrebtovy" Wildlife Preserve; Komi Science Center of Ural Branch of Russian Academy of Sciences: Syktyvkar, Russia, 2010; pp. 1-140. (In Russian)

39. Melekhina, E.N. On the fauna of the oribatid mites (Acari: Oribatida) of the Pechoro-Ilychsky Nature Reserve. In Proceedings of the Pechoro-Ilychsky Nature Reserve; Komi Science Center of Ural Branch of Russian Academy of Sciences: Syktyvkar, Russia, 2005; Volume 14, pp. 113-117. (In Russian).

40. Melekhina, E.N. Taxonomic diversity and areology of oribatid mites (Oribatei) of the European North of Russia. Proc. Komi Sci. Cent. Ural Division Russ. Acad. Sci. 2011, 2, 30-37. (In Russian)

41. Krivolutsky, D.A.; Lebren, F.; Kunst, M.; Akimov, I.A.; Bayartogtokh, B.; Vasiliu, N.; Golosova, L.D.; Grishina, L.G.; Karppinen, E.; Kramnoy, V.J.; et al. Oribatid Mites: Morphology, Development, Phylogeny, Ecology, Research Methods, and Characteristic of the Model Species Nothrus palustris C.L. Koch, 1839; Nauka: Moscow, Russia, 1995; pp. 1-223. (In Russian)

42. Gilyarov, M.S. The Key to Identify Soil Mites. Sarcoptiformes; Nauka: Moscow, Russia, 1975; pp. 1-488. (In Russian) 
43. Subías, L.S. Listado Sistemático, Sinonímico y Biogeográfico de Los Ácaros Oribátidos (Acariformes: Oribatida) del Mundo (Excepto Fósiles). Graellsia, 60 (Número Extraordinario). 2004; 305p. Available online: http://bba.bioucm.es/cont/docs/RO_1.pdf (accessed on 31 March 2019).

44. Karppinen, E.; Krivolutsky, D.A. List of oribatid mites (Acarina, Oribatei) of northern palaearctic region. 1. Europe. Acta Entomol. Fenn. 1982, 41, 1-18.

45. Golosova, L.; Karppinen, E.; Krivolutsky, D.A. List of oribatid mites (Acarina, Oribatei) of northern palaearctic region. II. Siberia and the Far East. Acta Entomol. Fenn. 1983, 43, 1-14.

46. Karppinen, E.; Krivolutsky, D.A.; Poltavskaja, M.P. List of oribatid mites (Acarina, Oribatei) of northern palaearctic region. III. Arid lands. Ann. Entomol. Fenn. 1986, 52, 81-94.

47. Behan-Pelletier, V. Oribatid mites (Acari: Oribatida) of the Yukon. In Insects of the Yukon; Danks, H.V., Downes, J.A., Eds.; Biological Survey of Canada: Ottawa, ON, Canada, 1997; pp. 115-149.

48. Ryabinin, N.A.; Pankov, A.N. Catalogue of Oribatid Mites of the Far East of Russia. Part II. Continental Part of the Far East; Far Eastern Branch of the Russian Academy of Sciences: Vladivostok-Khabarovsk, Russia, 2002; pp. 1-92.

49. Danks, H.V. Arctic artropods. A Reviev of Systematics and Ecology with Particular Reference to the North American Fauna; Entomological Society of Canada: Ottawa, ON, Canada, 1981; pp. 1-608.

50. Zenkova, I.V.; Zaitsev, A.S.; Zalish, L.V.; Liskovaya, A.A. Soil-dwelling oribatid mites (Acariformes: Oribatida) of the taiga and tundra zones of the Murmansk Region. Proc. Karelian Sci. Cent. Russ. Acad. Sci. 2011, 1, 54-67. (In Russian)

51. Tatarinov, A.G. Geography of Lepidoptera Diurnalis in the European Northeast of Russia; KMK Scientific Publications: Moscow, Russia, 2016; pp. 1-255.

52. Melekhina, E.N. Variety of fauna and geographical distribution of the oribatid mites (Oribatida) of the taiga zone of the European North-East. In Regularities in the Zonal Organization of Complexes of the Animal Population in the European North-East; Komi Science Center of Ural Branch of Russian Academy of Sciences: Syktyvkar, Russia, 2005; Volume 177, pp. 258-274. (In Russian)

(C) 2020 by the author. Licensee MDPI, Basel, Switzerland. This article is an open access article distributed under the terms and conditions of the Creative Commons Attribution (CC BY) license (http://creativecommons.org/licenses/by/4.0/). 